\title{
Economic growth, public, and private investment returns in 17 OECD economies
}

\author{
António Afonso ${ }^{1}$ (D) \& Miguel St. Aubyn ${ }^{1}$
}

Received: 10 July 2017 / Accepted: 15 February 2018 /Published online: 26 February 2018

\# ISEG 2018

\begin{abstract}
We study the macroeconomic effects of public and private investment in 17 OECD economies through a VAR analysis with annual data from 1960 to 2014. From impulse response functions we find that public investment had a positive growth effect in most countries, and a contractionary effect in Finland, UK, Sweden, Japan, and Canada. Public investment led to private investment crowding o ut in Belgium, Ireland, Finland, Canada, Sweden, the UK and crowding-in effects in the rest of the countries. Private investment has a positive growth effect in all countries; crowds-out (crowds-in) public investment in Belgium and Sweden (in the rest of the countries). The partial rates of return of public and private investment are mostly positive. Our results are robust to the ordering of private and public investment in the VAR.
\end{abstract}

Keywords Fiscal policy · Public investment · Private investment · Crowding-in · Macroeconomic rates of return - Impulse response functions · VAR

JEL Classification $\mathrm{C} 32 \cdot \mathrm{E} 22 \cdot \mathrm{E} 62$ 